\title{
Effect of Diatomaceous Earths on Mortality, Progeny and Weight Loss Caused by Three Primary Pests of Maize and Wheat in Kenya
}

\author{
Ngatia Christopher Mugo*, Mbugua John Nderi, Mutambuki Kimondo
}

Kenya Agricultural Research Institute (KARI), Nairobi, Kenya

Email address:

chrisngatia@gmail.com (Ngatia C. M.)

\section{To cite this article:}

Ngatia Christopher Mugo, Mbugua John Nderi, Mutambuki Kimondo. Effect of Diatomaceous Earths on Mortality, Progeny and Weight Loss Caused by Three Primary Pests of Maize and Wheat in Kenya. International Journal of Science, Technology and Society. Vol. 3, No. 3, 2015, pp. 76-82. doi: 10.11648/j.ijsts.20150303.12

\begin{abstract}
The Kensil fine (KF) dust was evaluated under laboratory conditions for the control of three important storage insect pests of maize and wheat. Serial concentrations of KF, Dryacide (DA) and Wood ash (Ash) were admixed with 100g of maize or wheat in ventilated glass jars. Mortality of $S$. zeamais, P. truncatus and $R$. dominica was assessed at 7, 14, 28, 56 and 84 days interval after grain treatment. At 28 days, all the three dusts effectively controlled S. zeamais with $95 \%-100 \%$ mortality while only DA was effective against $P$. truncatus. Both KF and Ash, with $84 \%$ and $92 \%$ mortality, did not reach the threshold required for $P$. truncatus. Mortality in $R$. dominica only peaked after 56 days but again only DA treatment was effective at 84 days. The delayed effect of the Diatomaceous earths (DE) and ash treatments appear to contribute to the higher damage inflicted; hence more weight loss than was expected. At 28 days mean sample weight loss by $S$. zeamais was $4.5 \%$ while $P$. truncatus and $R$. dominica caused $4.2 \%$ and $3.5 \%$ respectively. The emerged progeny after 14 days exposure to the three dusts was different for each pest with DA producing the least and KF the most. These results formed the criteria on which to base future trials under simulated farmer storage practice.
\end{abstract}

Keywords: Diatomaceous Earths, Delayed Effect, Grain Storage, Farmer Practice, Pest Control

\section{Introduction}

Storage insect pests have been linked with reduced income and food insecurity at farm household level (Stathers, 2002). Studies show the Sitophilus zeamais Motschulsky and the Prostephanus truncatus Horn are among the main storage insect pests of maize, (Golob et al., 1996; Brice et al., 1996, Marshland \& Golob 1996; Donaldson et al., 1996) while the Rhizopertha dominica prefers smaller grains like sorghum and wheat (Navarro and Donahaye, 1976). In their effort to mitigate losses, farmers either sell their harvested grain early or use different means of grain protection including traditional methods (Golob, et al., 1983). The use of chemicals among farmers has been on the rise, though the impact of insect infestation in terms of grain damage and weight loss also appears to display an upward trend (de Lima 1979; Muhihu and Kibata, 1985; Mutambuki and Ngatia, 2006).

Coupled with inherent problems like the development of resistance, risks of exposure to toxic pesticides, environmental contamination and zero tolerance in the grain trade, the urge to replace chemical pesticides with effective, safe and environmentally friendly pest control products seems imminent. Kuronic, (1997) noted that diatomaceous earths (DEs), the fossilized skeletons of diatoms, have the greatest potential to replace pesticides. They have low mammalian toxicity (Golob 1997 and Kuronic 1998) and can control a wide range of stored products insect pests (Barbosa et al., 1994; Subramanyam et al., 1998; Mewis \& Ulrichs 2001; Arthur, 2002; Arthur \& Throne 2003; Athanassiou et al., 2005; Wakil et al., 2010). Their potency does not expire and can therefore protect grain during a storage season (Stathers, et al., 2004). Ebeling (1971) explains that DEs work by absorbing the epicuticular lipids which leads to excessive water loss and death of insects.

DEs are found in different parts of the world, and based on their physical properties and the diatom species, Kuronic (1997, 1998) found significant differences in their efficacy 
against insects. Athanassiou, et al., (2003) added the grain type (Fields \& Kuronic 2002; Nikpay 2006; Athanassiou et al., 2006) and grain moisture, temperatures and relative humidity also influence their efficacy. The fact that DEs can combine with chemical pesticides, (Stathers, 2002; Ceruti and Lazzari, 2005), or bio-control organisms to enhance potency (Lord, 2001; Akbar et al., 2004) appear to attract local commercial interests aimed at broadening the areas of use for the DEs. The main hindrance is the stringent regulatory requirements enforced by the Pest Control Products Board (PCPB) which recommends local efficacy trials before any pest control product can be registered. Towards this requirement, the African Diatomite Industries Limited (ADIL), requested the Kenya Agricultural Research Institute (KARI) to evaluate Kensil $\mathrm{F}$ before seeking its registration for use in the storage sector. This paper describes the laboratory evaluation process for Kensil Fine (KF) dust which was compared with Dryacide (DA) from Australia and Wood ash (Ash) for their control of three important stored products insect pests.

\section{Materials and Methods}

\subsection{Grain Conditioning and Treatment}

A $90 \mathrm{~kg}$ bag of freshly harvested maize and $45 \mathrm{~kg}$ of wheat were fumigated in metal drums using phosphine gas generating tablets for 7 days. The grain was then screened over a sack sieve (maize) and $1 \mathrm{~mm}$ aperture test sieve (wheat) to remove dust and non-grain material. A $100 \mathrm{~g}$ of maize were put in each of the 720 glass jars of 300cc capacity, half of which were closed with wire gauze and the remaining with watman filter papers. The jars closed with wire gauze were then grouped into 4 lots of 90 and again divided into 5 batches of 18 jars of which a set of 3 replicates was treated with $0,0.1 \%, 0.2 \%, 0.3 \%, 0.4 \%$ and $0.5 \% \mathrm{w} / \mathrm{w}$ serial doses of Kensil F, Dryacide or Wood Ash. The same was repeated for the jars closed with filter paper. A similar quantity $(100 \mathrm{~g})$ of wheat in another 360 jars closed with filter paper was treated in the same way.

\subsection{Introduction of Test Insects}

Sitophilus zeamais (Motschulsky) Prostephanus truncatus (Horn) and Rhizopertha dominica (F.), all ex laboratory cultures maintained on whole maize and wheat grain at $25 \pm 5^{\circ} \mathrm{C}$ and $70 \% \pm 2 \%$ relative humidity (r.h) were used. Twenty unsexed but active adult $S$. zeamais were introduced into each of the 90 jars with maize treated with KF and repeated for jars treated with DA and Ash respectively. A similar number of $P$. truncatus adults were introduced into the maize jars closed with wire gauze (to check escape) and treated with the three dusts. Finally, the process was repeated for $R$. dominica in wheat jars. All the jars were randomly placed in the temperature control room (TCR) set at $25 \pm 5^{\circ} \mathrm{C}$ and $70 \pm 2 \%$ relative humidity. Mortality of the parent population was assessed after 7 days exposure for each of the post-treatment intervals of 7, 14, 28, 56 and 84 days. Any increase especially after 28 days was classified as the $F_{1}$ progeny.

\subsection{Progeny Monitoring}

Progeny monitoring was done only in the jars exposed for 14 days. After accounting for the parental population, the jars were incubated in the same CTR for a further 21 days before the contents were sieved and the status of the recovered adult insects noted. Sieving to remove emerged insects was repeated at 2-day interval until all the jars failed to produce any adults for three consecutive attempts when the total emergence per jar was noted.

\subsection{Estimate of Weight Loss in Samples}

Grain weight reduction occasioned by insect feeding was calculated from the differences between the original and the final weight in each jar and the results expressed as percentage using Harris and Lindblad (1978) derivative formula below:

$$
\% w t \text { loss }=\frac{w_{1}-w_{2} \times 100}{w_{1}}
$$

Where

$\mathrm{W}_{1}=$ Original weight without inert dust; $\mathrm{w}_{2}=$ Final weight without inert dust.

\subsection{Data Handling and Analysis}

Data on mortality, $F_{1}$ emergence and weight loss was managed with the Excel and analyzed using the statgraphic softwares. ANOVA indicated the main factors that influenced insect mortality while Least Significant Difference (LSD) separated treatment means that significantly contributed to the difference at $95 \%$ level of confidence.

\section{Results and Discussion}

\subsection{Results}

\subsubsection{Mortality of Test Insects Exposed to DE on Treated Maize or Wheat}

The ANOVA showed that post-treatment period, pest species and applied dust treatments significantly $(\mathrm{P}=0.0000)$ influenced mortality of test insects (Table 1). Insect mortality was different from one interval to the next and for S. zeamais and $R$. dominica it increased with storage period. Mortality of $P$. truncatus fluctuated between intervals and Dryacide was the most effective among the three dusts.

Table 2 shows the effect of the three dusts on the mortality of the test insects. At 7 days, Kensil F controlled only $37 \%$ of the $S$. zeamais, which increased to $97 \%$ at 28 days. Dryacide and Ash were significantly ( $\mathrm{P}=0.0003$ ) better at $69 \%$, rising to $100 \%$ and $96 \%$ respectively for same period. After 28 days, insect mortality dropped but increased again at 84 days.

Mortality in P. truncatus was much lower, at between $23 \%$ and $44 \%$ at 7 days across dust treatments and thereafter fluctuated up and down between intervals. Again, Kensil F 
performed poorly and was not significantly $(\mathrm{P}=0.05)$ different from Ash. Between 7 and 14 days, mortality in Dryacide treatment was significantly different from the control. At 28 days, the three dusts controlled $84 \%, 96 \%$ and $92 \%$ respectively showing great improvement. After 28 days, pest mortality declined but Dryacide maintained a clear lead from the other dusts.

When applied on wheat to control $R$. dominica, the three dusts recorded even lower mortality compared with that in $S$. zeamais and $P$. truncatus in maize. At 7 days, Kensil only achieved $11 \%$ compared with $17 \%$ and $25 \%$ for Ash and Dryacide respectively. At 28 days, mortality in Kensil treated maize had risen almost by four-folds to $43 \%$ while that in
Dryacide treatment had increased by more than three-folds to $92 \%$. Dryacide then progressed to effective level (>95\%) at 84 days while both Kensil $\mathrm{F}$ and Ash only attained $68 \%$ and $81 \%$ respectively at 56 days. The data portrays a close relationship between Ash and Kensil and that the three dusts were a better alternative to no control. Figure 1 shows the performance of individual dusts based on average mortality as compared with the control. Among the dusts the superiority of Dryacide as a grain protectant was confirmed. $S$. zeamais was the most susceptible followed by $R$. dominica and $P$. truncatus. All the dust treatments indicate the benefits to be gained if farmers could use them for protecting stored grain.

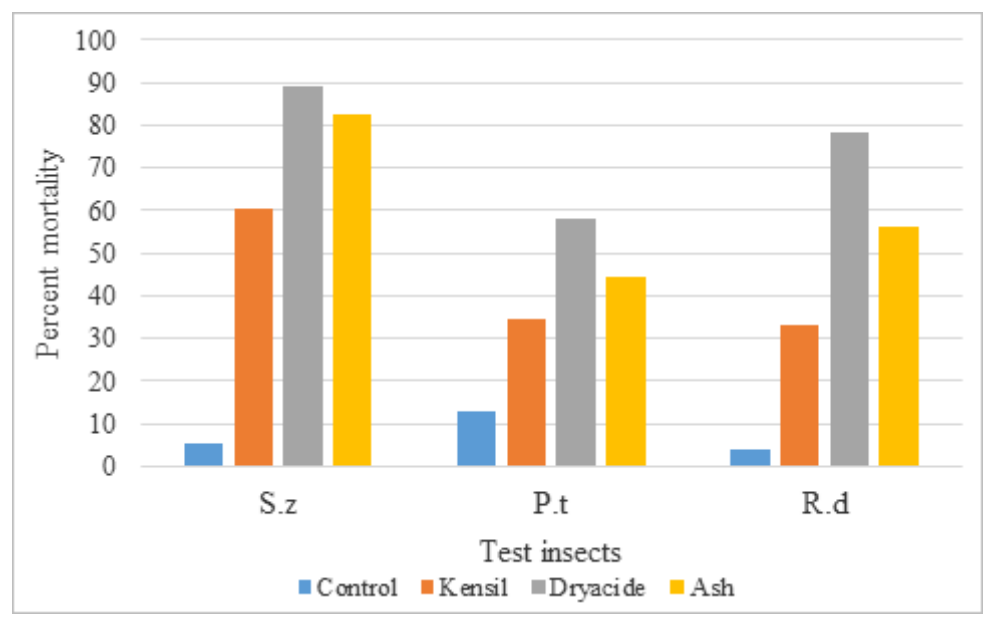

Fig. 1. The influence of dust treatments on the mortality of three test insects as compared with the control. Key: S.z = Sitophilus zeamais; P.t = Prostephanus truncatus; R.d $=$ Rhizopertha dominica.

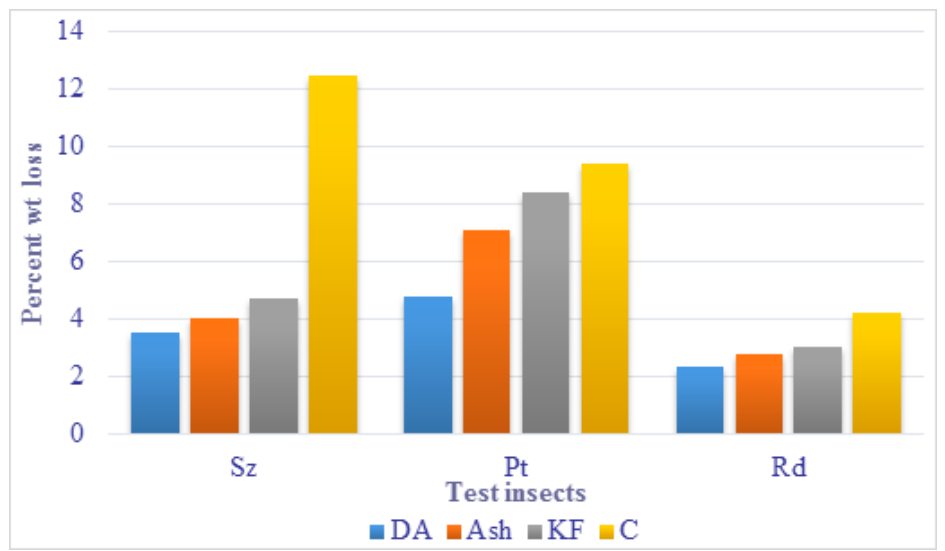

Fig. 2. The influence of dust treatments on percent weight loss in grain samples exposed to three test insects. Key: S.z $=$ Sitophilus zeamais; P.t $=$ Prostephanus truncatus; $R$. $d=$ Rhizopertha Dominica ; $D A=$ Dryacide, $K F=$ Kensil fine, $C=$ control.

\subsubsection{The Potential of DE to Protect Stored Grain from Damage by Insect Pests}

The potential of Kensil Fine to protect stored grain was assessed from the level of grain damage and its subsequent weight loss. Table 3 shows the level of sample weight loss in both maize and wheat when compared with the control. At 14 day interval, dust treatments recorded between $2 \%$ and $3 \%$ in S. zeamais infested maize compared with almost $7 \%$ for the control. Dryacide had the lowest while there was no statistical difference between Ash and Kensil. At 28 days, both Ash and Kensil recorded 4.6\% and 5.1\% weight loss, an indication that their effectiveness was weak, a situation which persisted to 84 days. With $2.1 \%-4.4 \%$ weight loss, Dryacide was the only effective protectant against $S$. zeamais. The benefit of applying protection can be worked out from comparing treatment figures against the control at each interval. P. truncatus appear to be the most damaging, and despite the dust application, weight loss between $4.6 \%$ and $10.3 \%$ was recorded at 7 days across the treatments. However, weight loss dropped by a factor of between 0.4 and $0.8(20 \%$ 
and $59 \%$ ) at 28 days, but gradually increased to $6.5 \%-13.7 \%$ at 84 days. At every interval, Dryacide had the lowest figures and compared with Kensil, the differences were highly significant $(\mathrm{P}=0.0000)$, only comparable with the control. Wheat suffered between $2 \%$ and $6 \%$ weight loss from $R$. dominica infestation in spite of the treatments applied. At 14 days, all treatments recorded between $1.9 \%$ and $2.3 \%$ weight loss as compared with $3.1 \%$ for the control. Highest weight loss (of between 3.1\% and 3.8\%) was recorded at 28 days with Dryacide having the lowest and Kensil the opposite. From 28 days, sample weight loss progressively dropped and at 84 days only Kensil reached 3.3\% level. However, all treatments were significantly $(\mathrm{P}<0.05)$ better than the control. Figure 2 illustrates the protective benefit accorded by the applied dusts on stored grain against the damage from test insects. It is clear that more benefit would be realized if the pest was $S$. zeamais and not others.

\subsubsection{Emergence of F1 Progeny of Test Insects from DE Treated Grain}

Varying numbers of $F_{1}$ progeny emerged from the eighteen jars that were used from each treatment (Table 4). More progeny emerged from maize than wheat and $S$. zeamais had consistently lower numbers (between 7 and 30), compared with $19-87$ for $P$. truncatus. It was not clear why $R$. dominica produced negligible progeny of between 1 and 2 adults across the treatments including the control. Figure 3 shows the influence of the dust treatments on the emerged progeny. Although all treatments significantly $(\mathrm{P}=0.0000)$ suppressed progeny emergence, Dryacide was markedly better with below 20 adults. Kensil and Ash could not effectively suppress $P$. truncatus, the most destructive of the three test insects, indicating reduced protection of grain.

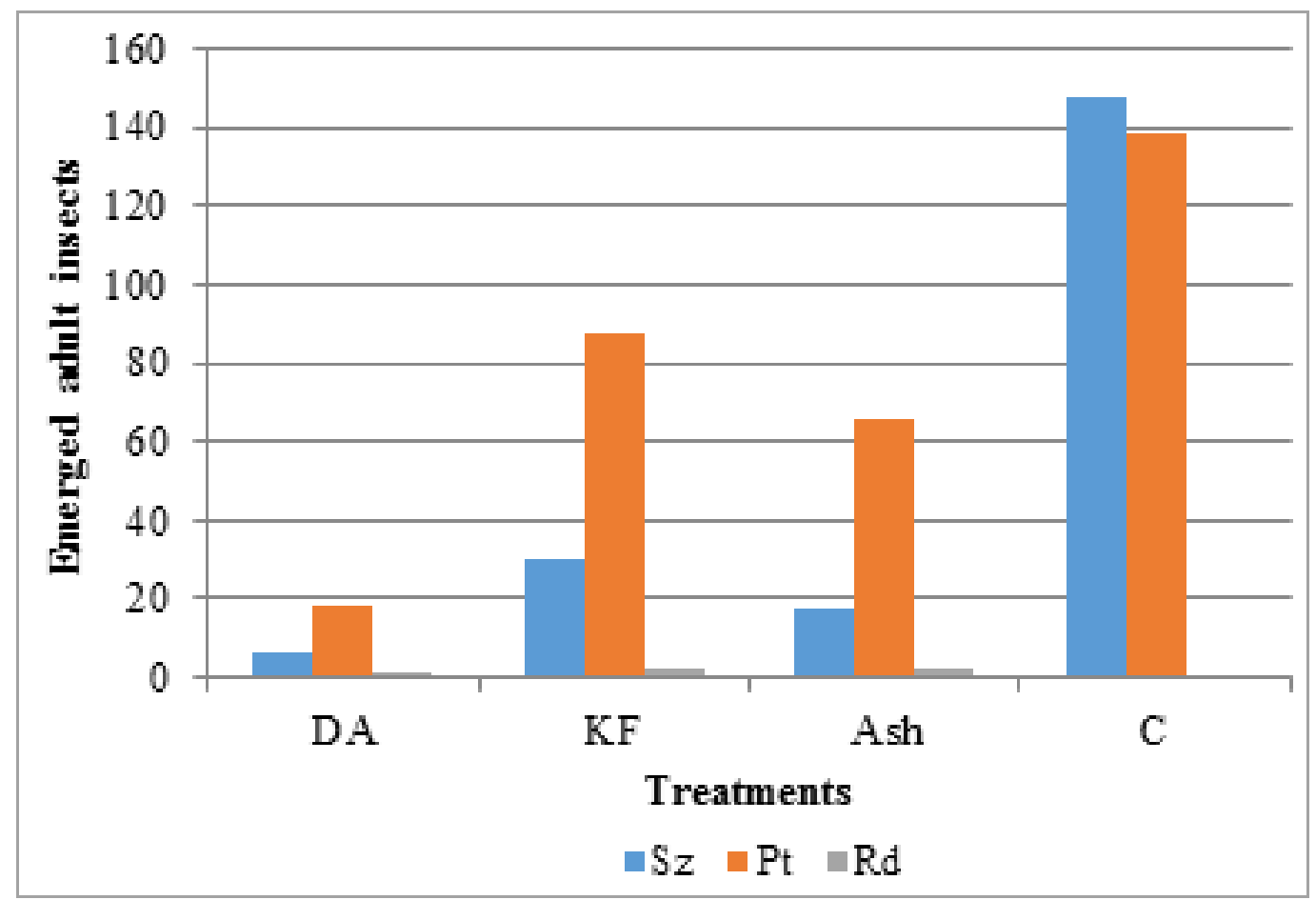

Fig. 3. Progeny that emerged from Sitophilus zeamais (Sz), Prostephanus truncatus (Pt) and Rhizopertha dominica (Rd) after 14 day exposure on maize/wheat treated with Dryacide (DA), Kensil fine $(K F)$ and Ash compared with untreated control.

\subsection{Discussion}

The lab bioassay was set up to generate various data sets that could give a trend in efficacy of Kensil F, a locally mined diatomaceous earth. From the results, the mode of action clearly emerged where mortality was gradual, reaching the peak in 28 days for $S$. zeamais and $P$. truncates respectively. The peak for $R$. dominica was at 56 days. This contrasts with findings in some lab studies where DEs recorded $100 \%$ mortality between 7 and 14 days (Collins and Cook, 2006; Athanassiou et al., 2004). In this study the delay was probably due to the absorptive process of the epicuticle described by Ebeling (1971), a clear difference from the almost instant mortality normally observed in chemical trials. Although mortality trend was similar for all test insects, the level of control showed different pest responses with Sitophilus zeamais being more susceptible than the grain borers. Kuronic (1997 and 1998) had stated pest species as a factor in DE efficacy, which could partly be due to specific pest behaviour (borers, in the open tend to be docile and less active while they actively bore into the grain almost immediately after introduction). Such behaviour tend to reduce the chances of abrasion from the dusts which would improve if the insect moved about among DE treated grain. With delayed mortality, test insects had ample time to bore into grain, feed and reproduce, a fact confirmed by a second grain damage peak at 12 weeks. The impact of insect damage directly relates to percent weight loss noted. Grain damage is therefore the main criterion used to judge the protection 
capacity of a candidate product. The Pest Control Products Board, a Kenya Government regulatory body considers $>5 \%$ as the ceiling for acceptance to license and register chemical pesticides for use in the storage sector. Higher damage levels also translate to higher weight loss which has a bearing on market value and trade. In this trial, the extensive damage by $P$. truncatus was thus responsible for higher $(>5 \%)$ weight loss especially in maize treated with either Ash or Kensil F. This again was a reflection of the pest behaviour, and between the two borers, $P$. truncatus was the more voracious feeder and quickly bored into the grain thereby avoiding too much contact with grain protectant. These assumptions will be considered during the simulation trial. The data also allows the calculation of differential loss farmers would suffer by applying a less effective dust. Using Dryacide as the best option during this trial, a farmer would suffer $1.21 \%$ for applying Kensil F on maize infested with $S$. zeamais, or $3.6 \%$ if $P$. truncatus was the pest. For wheat, the difference was much smaller $(0.35 \%)$ but the proportional loss could be higher considering the grain size compared to that of maize.

\section{Conclusion}

The rising interest in DEs has been responsible for many studies some of which have led to commercial exploits. This pilot trial will contribute greatly to the understanding of how the DEs work before formal registration for use in the storage sector in Kenya. It will also help to expand the areas of use for Kensil, while farmers will have a novel alternative to chemical pesticides. Though DEs have a definite role to play in the management of storage insect pests, the study has shown that they are not instant in their efficacy as would be for chemical pesticides. They require actively mobile insects among the treated grain to abrade the waxy layer which prevents excessive water loss from their bodies. These were the behavioral differences between $S$. zeamais and $P$. truncatus. The data generated promising trends and it was left to the proprietor to consider refining the physical properties (size) of Kensil before the research body could plan advanced trials.

Table 1. ANOVA for mortality of test insects exposed to Kensil F, Dryacide and Ash

\begin{tabular}{llllll}
\hline Source & Sum of Squares & df & Mean Square & F- Ratio & P-Value \\
\hline MAIN EFFECTS & & & & & 82.79 \\
A: Weeks & 171997 & 4 & 42999.2 & 109.09 & 0.0000 \\
B: Pests & 113318 & 2 & 56658.9 & 150.04 & 0.0000 \\
C: Treatment & 233782 & 3 & 77927.0 & 0.62 & 0.0000 \\
D: Reps & 640.631 & 2 & 320.316 & & 0.5400 \\
RESIDUAL & 367721 & 708 & 519.38 & & \\
TOTAL (CORRECTED) & 88745 & 719 & & & \\
\hline
\end{tabular}

All $\mathrm{F}$ - ratios are based on the residual mean square error.

Table 2. Percent mortality of test insects when exposed to three inert dusts applied on stored maize or wheat

\begin{tabular}{|c|c|c|c|c|c|c|}
\hline \multicolumn{7}{|c|}{ Maize weevil (Sitophilus zeamais) } \\
\hline \multicolumn{7}{|c|}{ Treatments Post treatment period (weeks) } \\
\hline 1 & 2 & 4 & 8 & 12 & Mean & \\
\hline $\mathrm{C}$ & $8.3 \mathrm{a}$ & $11.7 \mathrm{a}$ & $1.7 \mathrm{a}$ & $2.3 \mathrm{a}$ & $3.7 \mathrm{a}$ & 5.54 \\
\hline $\mathrm{KF}$ & $37.3 \mathrm{a}$ & $52.0 \mathrm{~b}$ & $97.0 \mathrm{~b}$ & $38.3 b$ & $77.6 \mathrm{~b}$ & 60.44 \\
\hline DA & $68.7 \mathrm{~b}$ & $94.7 \mathrm{c}$ & $100 \mathrm{~b}$ & $83.1 \mathrm{~d}$ & $98.6 \mathrm{c}$ & 89.02 \\
\hline Ash & $68.9 b$ & $82.7 \mathrm{c}$ & $95.7 b$ & $72.1 \mathrm{c}$ & $92.9 \mathrm{c}$ & 82.46 \\
\hline$P$ value & 0.0003 & 0.0000 & 0.0000 & 0.00000 .0000 & & \\
\hline \multicolumn{7}{|c|}{ Larger grain borer (Prostephanus truncatus) } \\
\hline $\mathrm{C}$ & $3.3 \mathrm{a}$ & $20.0 \mathrm{ab}$ & $26.7 \mathrm{a}$ & $5.8 \mathrm{a}$ & $9.2 \mathrm{a}$ & 13.0 \\
\hline $\mathrm{KF}$ & $22.7 \mathrm{ab}$ & $17.3 \mathrm{a}$ & $84.0 \mathrm{~b}$ & $36.8 \mathrm{ab}$ & $12.7 \mathrm{a}$ & 34.7 \\
\hline DA & $43.7 \mathrm{c}$ & $35.0 \mathrm{~b}$ & $95.7 \mathrm{c}$ & $63.1 \mathrm{c}$ & $53.9 b$ & 58.28 \\
\hline Ash & $30.7 b$ & $21.0 \mathrm{a}$ & $91.7 \mathrm{c}$ & $50.7 \mathrm{bc}$ & $27.6 \mathrm{a}$ & 44.34 \\
\hline$P$ value & 0.0004 & 0.0174 & 0.0000 & 0.0024 & 0.0000 & \\
\hline \multicolumn{7}{|c|}{ Lesser grain borer (Rhizopertha dominica) } \\
\hline $\mathrm{C}$ & $0.0 \mathrm{a}$ & $3.3 \mathrm{a}$ & $1.7 \mathrm{a}$ & $12.4 \mathrm{a}$ & $3.4 \mathrm{a}$ & 4.16 \\
\hline $\mathrm{KF}$ & $11.2 \mathrm{a}$ & $17.7 \mathrm{a}$ & $42.6 \mathrm{a}$ & $68.4 \mathrm{a}$ & $27.0 \mathrm{a}$ & 33.38 \\
\hline DA & $25.4 b$ & $82.4 c$ & $91.6 \mathrm{c}$ & $94.1 \mathrm{~b}$ & $97.6 \mathrm{c}$ & 78.22 \\
\hline Ash & 17.1ab & $57.2 \mathrm{~b}$ & $64.1 b$ & $61.4 \mathrm{a}$ & $80.7 b$ & 56.1 \\
\hline$P$ value & 0.0169 & 0.0000 & 0.0000 & 0.0000 & 0.0000 & \\
\hline
\end{tabular}

NB: Each datum is a mean of 15 dose reps.

Column numbers followed by same letter were not statistically different at 95\% level (DMRT). 
Table 3. Percent weight loss caused by three storage insect pests on maize/wheat treated with three inert dusts

\begin{tabular}{|c|c|c|c|c|c|}
\hline \multicolumn{6}{|c|}{ Sitophilus zeamais } \\
\hline \multicolumn{6}{|c|}{ Post treatment storage period (weeks) } \\
\hline Treatments & 2 & 4 & 8 & 12 & Mean \\
\hline DA & $2.12 \mathrm{a}$ & $3.89 \mathrm{a}$ & $3.66 \mathrm{a}$ & $4.38 \mathrm{a}$ & 3.51 \\
\hline Ash & $2.65 \mathrm{~b}$ & $4.55 \mathrm{~b}$ & $4.22 \mathrm{a}$ & $4.75 \mathrm{a}$ & 4.04 \\
\hline $\mathrm{KF}$ & $3.07 \mathrm{~b}$ & $5.10 \mathrm{c}$ & $4.96 \mathrm{c}$ & $5.76 \mathrm{~b}$ & 4.72 \\
\hline $\mathrm{C}$ & $6.93 \mathrm{c}$ & $12.33 \mathrm{c}$ & $9.20 \mathrm{c}$ & $21.27 \mathrm{c}$ & 12.43 \\
\hline$P$ value & 0.0000 & 0.0000 & 0.0000 & 0.0000 & \\
\hline \multicolumn{6}{|c|}{ Prostephanus truncatus } \\
\hline $\mathrm{DA}$ & $4.55 \mathrm{a}$ & $3.69 \mathrm{a}$ & $4.35 \mathrm{a}$ & $6.50 \mathrm{a}$ & 4.77 \\
\hline Ash & $8.64 b$ & $4.57 \mathrm{~b}$ & $5.07 \mathrm{~b}$ & $9.94 \mathrm{~b}$ & 7.06 \\
\hline $\mathrm{KF}$ & $10.31 \mathrm{c}$ & $4.28 \mathrm{ab}$ & $5.32 \mathrm{~b}$ & $13.72 \mathrm{c}$ & 8.41 \\
\hline $\mathrm{C}$ & $12.23 \mathrm{c}$ & $7.17 \mathrm{c}$ & $5.67 \mathrm{~b}$ & $12.40 \mathrm{bc} 9.37$ & \\
\hline$P$ value & 0.0000 & 0.0001 & 0.0069 & 0.0000 & \\
\hline \multicolumn{6}{|c|}{ Rhizopertha dominica } \\
\hline DA & $1.85 \mathrm{a}$ & $3.07 \mathrm{a}$ & $2.47 \mathrm{a}$ & $2.04 \mathrm{a}$ & 2.36 \\
\hline Ash & $2.23 \mathrm{ab}$ & $3.53 b$ & $2.73 b c$ & $2.58 \mathrm{ab}$ & 2.76 \\
\hline $\mathrm{KF}$ & $2.30 \mathrm{~b}$ & $3.79 \mathrm{~b}$ & $2.69 \mathrm{~b}$ & $3.27 \mathrm{~b}$ & 3.01 \\
\hline $\mathrm{C}$ & $3.13 b$ & $4.87 \mathrm{c}$ & $3.00 \mathrm{c}$ & $5.87 \mathrm{c}$ & 4.22 \\
\hline$P$ value & 0.0222 & 0.0000 & 0.0017 & 0.0000 & \\
\hline
\end{tabular}

Column means followed by same letter were not statistically different at $\mathrm{P}=0.05$

Each datum is a mean of 15 dose levels

Table 4. Effect of inert dusts applied on maize or wheat on the emergence of $F_{1}$ progeny of three storage insect pests after 14 day exposure

\begin{tabular}{llllll}
\hline \multirow{2}{*}{ Pest } & Applied treatments & & & & Control \\
\cline { 2 - 6 } & DA & Ash & KF & $148.0 \mathrm{~d}$ & Pvalue \\
\hline S. zeamais & $6.87 \mathrm{a}$ & $17.07 \mathrm{~b}$ & $29.73 \mathrm{c}$ & 0.0000 \\
P. truncatus & $18.6 \mathrm{a}$ & $65.93 \mathrm{~b}$ & $87.27 \mathrm{~b}$ & $138.0 \mathrm{c}$ & 0.0000 \\
R. dominica & $1.13 \mathrm{a}$ & $2.0 \mathrm{a}$ & $2.13 \mathrm{a}$ & $0.7 \mathrm{a}$ & $\mathrm{ns}$ \\
\hline
\end{tabular}

Each datum is a mean of 15 observations

Row numbers followed by same letter were not statistically different at $\mathrm{P}=0.05$.

\section{Acknowledgement}

This study could not have progressed to fruitful conclusion without the intervention or participation of certain persons and institutions. The authors would like to sincerely acknowledge the drive and support by the African Diatomite Industries Limited (ADIL) who, initiated the Kensil evaluation process to widen its use from beverage and paint industries to include agriculture. Special mention goes to $\mathrm{Mr}$. Philip Chesang for actively monitoring the progress of the work at all project sites and ensuring continuous project funding which is greatly acknowledged. Many thanks go to the KARI Management through our Centre Director for creating conducive environment under which the work was carried out. The authors greatly appreciate those others who cannot be named for playing different roles.

\section{References}

[1] Akbar, W., Lord, J. C., Nichols, J. R. and Howard, R. W., 2004: Diatomaceous earth increases the efficacy of Beauveria bassiana against Tribolium castaneum larvae and increases conidia attachment. Journal of Economic Entomology. 97 (2): $273-280$ (2004).
[2] Arthur, F., 2002: Survival of Sitophilus oryzae (L.) on wheat treated with diatomaceous earth: impact of biological and environmental parameters on product efficacy. Journal of Stored Product Research. 38 (2002) $305-313$.

[3] Arthur, F. H. and Throne, J. E., 2003: Efficacy of Diatomaceous Earth to control internal infestation of rice and maize weevils (Coleoptera: Curculionidae). Journal Economic Entomology, 96 (2): 510 - 518.

[4] Athanassiou, C. G., Kavallieratos, N. G., Vaiyas, B. J., Dimizas, C. B., Buchelos, C. Th. and Tsaganou, F. C., 2003: Effect of grain type on the insecticidal efficacy of SilicoSec against Sitophilus oryzae (L.) (Coleoptera: Curculionidae). Crop Protection. 22: $1141-1147$.

[5] Athanassiou, C. G., Vaiyas, B. J., Dimizas, C. B., Kavallieratos, N. G., Papagregoriou, A. S. and Buchelos, C. Th., 2005: Insecticidal efficacy of diatomaceous earth against Sitophilus oryzae (L.) (Coleoptera: Curculionidae) and Tribolium confusum du Val (Coleoptera: Tenebrionidae) on stored wheat: influence of dose rate, temperature and exposure interval. Journal of Stored Products Research 41 (2005) 47 55.

[6] Athanassiou, C. G., Vaiyas, B. J., Dimizas, C. B., Kavallieratos, N. G. and Tomanovic, Z., 2006: Factors affecting the insecticidal efficacy of the diatomaceous earth formulation SilocoSec ${ }^{\circledR}$ against adults of the rice weevil, Sitophilus oryzae (L.) (Coleoptera: Curculionidae). Applied Entomology. Zool. 41 (2): 201 - 207 (2006). 
[7] Barbosa, A., Golob, P. and Jenkins, N., 1994: Silica aerogels as alternative protectants of maize against Prostephanus truncatus (Horn) (Coleoptera: Bostrichidae) infestations. In: Highley, E. J., Banks, H. G., Champ, B. R. (Eds) Stored Product Protection, Vol. 2. CAB International, Wallingford, UK.

[8] Brice, J., Moss, C., Marshland, N., Stevenson, S., Fuseini, H., Bediako, J., Gbetroe, H., Yeboah, R. and Ayuba, I., 1996: Post-harvest constraints and opportunities in cereal and Legume production systems in northern Ghana. NRI Research Report, 85pp.

[9] Collins, D. A. and Cook, D. A., 2006: Laboratory studies evaluating the efficacy of diatomaceous earths, on treated surfaces, against stored-product insect and mite pests. Journal of stored Products Research 42 (2006), 51 - 60.

[10] Ceruti, F. C. and Lazzari, S. M. N., 2005: Combination of diatomaceous earth and powder permethrin for insect control in stored corn. Revista Brasileira de Entomologia 49(4): 580 583, dezembro 2005.

[11] de Lima, C. P. F., 1979: The assessment of losses due to insects and rodents in maize stored for subsistence in Kenya. Tropical Stored Products Information, 1979. 38, 21 - 26.

[12] Donaldson, T., Marange, T., Mutikani, V., Mvimi, B., Nenguwi, N., Scarbrorough, V. and Turner, A. D., 1996: Household food security study: rapid rural appraisal of villages in three communal lands of Zimbabwe. NRI Research Report R2315(s). iv +50pp +annexes.

[13] Ebeling, W., 1971: Sorptive dusts for pest control. Annual Review of Entomology 16, 123 - 158.

[14] Fields, P. G. and Kuronic, Z. 2002: Post-harvest insect control with inert dusts. In: Pimentel, D. (Ed.), Dekker Encyclopedia of Pest Management. Marcel Dekker, New York, pp 650 - 653

[15] Golob, P., Dunstan, U. R., Evans, N., Meik, J., Reed, D. and Magazini,I., 1983: Preliminary field trials to control Prostephanus truncatus (Horn) in Tanzania. Tropical Stored Products Information. 45, pp $15-18$.

[16] Golob, P., Stringfellow, R. and Asante, E. O., 1996: A review of the storage and marketing systems of major food grains in northern Ghana. NRI Research Report, 64 pp.

[17] Golob, P., 1997: Current status and future perspectives for inert dusts for the control of stored product insects. Journal Stored Products Research. Vol. 33, No.1, pp 69 -79, 1997.

[18] Kuronic, Z., 1997: Rapid assessment of insecticidal value of diatomaceous earths without conducting bioassays. Journal of Stored Products Research. Vol. 33, No. 3, pp 219-229, 1997.
[19] Kuronic, Z., 1998: Review: diatomaceous earths, a group of natural insecticides. Journal of Stored Products Res. Vol. 34, No. 2/3, pp 87 - 97, 1998.

[20] Lord, J. C., 2001: Desiccant dusts synergize the effect of Beauveria bassiana (Hyphomycetes: Moniliales) on stored grain beetles. Journal of Economic Entomology. 94 (2): 367 372 (2001).

[21] Marshland, N. and Golob, P., 1996: Rapid rural appraisal of post maturity issues in the central region of Malawi. NRI Research Report R 2358(S) 36pp.

[22] Mewis, I. and Ulrichs, Ch., 2001: Action of amorphous diatomaceous earth against different stages of the stored product pests Tribolium confusum, Tenebrio molitor, Sitophilus granaries and Plodia interpunctella. Journal of Stored Products Research. 37 (2001) 153 - 164.

[23] Muhihu, S. K. and Kibata, G. N., 1985: Developing a control programme to combat an outbreak of Prostephanus truncatus (Horn) (Coleoptera: Bostrichidae) in Kenya. Tropical Science, 25: $239-248$.

[24] Mutambuki, K. and Ngatia, C. M., 2006: Loss assessment of on-farm stored maize in semi-arid areas of Kitui District, Kenya. In: Lorini, I., Bacultchuk, B., Beckel, H. and Deckles, D. Proceedings of the $9^{\text {th }}$ International Working Conference on Stored Product Protection, Campinas, Sao Paulo, Brazil, 15 23.

[25] Navarro, S. and Donahaye, E., 1976: Conservation of wheat grain in Butyl Rubber/EPDM containers during three storage seasons. Tropical Stored Products Information. 32, pp $13-23$.

[26] Nikpay, A., 2006: Diatomaceous earths as alternatives to chemical insecticides in stored grain. Insect Science. (2006) $13,421-429$.

[27] Stathers, T. E., 2002: Combinations to enhance the efficacy of diatomaceous earths against the larger grain borer, Prostephanus truncatus (Horn). In Credland, P. F., Armitage, D.M., Bell, C. H., Cogan, P. M. and Highley, E. (2003) (Eds). Advances in Stored Products Protection. York. UK.

[28] Stathers, T. E., Denniff, M. and Golob, P, 2004: The efficacy and persistence of diatomaceous earths admixed with commodity against four tropical stored product beetle pests. Journal of Stored Products Research, 40 (2004) 113 - 123.

[29] Subramanyam, Bh. Mudamanchi, N. and Norwood, S., 1998: Effectiveness of Insecto applied to shelled maize against stored product insect larvae. Journal of Economic Entomology. $91,280-286$.

[30] Wakil, W., Muhammad, A., Ghazanfar, M. U. and Tahira, R., 2010: Susceptibility of stored product insects to enhanced diatomaceous earth. Journal of Stored Product Research. 46 (2010) $248-249$. 